Sari Pediatri, Vol. 4, No. 3, Desember 2002: 147 - 151

\title{
Rapid Manual Test sebagai Alat Diagnostik Malaria falciparum
}

\section{Desrinawati}

Malaria adalah penyakit infeksi akut maupun kronis yang disebabkan oleh Plasmodium malariae dengan gejala klinis demam rekuren, anemia, dan hepatosplenomegali. Di Indonesia sampai saat ini penyakit malaria masih merupakan masalah kesehatan masyarakat. Diagnosis pada malaria dapat dilakukan dengan uji mikroskopis dan non mikroskopis. Rapid manual test termasuk uji non mikroskopis. Uji ini merupakan uji cepat, mudah dan tidak memerlukan laboratorium khusus. Rapid manual test dapat di bagi berdasarkan, Histidine Rich Protein-II (HRP-II) contoh kitnya ParaSight ${ }^{\circledR}$, Paracheck, ${ }^{\circledR} \mathrm{ICT}^{\circledR}$. Juga berdasarkan parasite lactate dehydrogenese $(\mathrm{pLDH})$ contoh kitnya $o p t i M A L^{\circledR}$. Kit-kit ini sudah diteliti di beberapa negara dengan hasil sensitivitas dari spesifisitas rata-rata di atas $90 \%$.

Kata kunci: Plasmodium falciparum, rapid manual test.

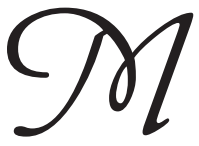

alaria adalah penyakit infeksi akut maupun kronis yang disebabkan oleh Plasmodium malariae dengan gejala demam rekuren, anemia, dan hepatosplenomegali. ${ }^{1}$ Terdapat bukti bahwa penyakit ini mempunyai tingkat endemisitas yang tinggi di beberapa kawasan pemukiman di daerah tropis dan subtropis sejak masa prasejarah. Hingga akhir dari pertengahan abad kedua puluh, masih terjadi 250 juta kasus setiap tahun di seluruh dunia, dan sekitar 2,5 juta manusia meninggal oleh penyakit ini setiap tahunnya. ${ }^{2}$ Khususnya pada bayi dan anak, angka kematian dan kesakitan pada umur di bawah 5 tahun adalah 6\%, dan $11 \%$, di Afrika $10 \%$ angka kematian pada anak disebabkan oleh malaria. ${ }^{3,4}$

Di Indonesia, sampai saat ini penyakit malaria masih merupakan masalah kesehatan masyarakat. ${ }^{1,3}$ Angka kesakitan penyakit ini masih cukup tinggi, terutama daerah luar Jawa dan Bali, yang memiliki campuran penduduk berasal dari daerah endemis dan

\footnotetext{
Alamat Korespondensi:

Dr. Desrinawati

Bagian Ilmu Kesehatan Anak FK. USU/ RSUP H. Adam Malik Medan. Jl. Bunga Lau No. 17 Medan.

Tel. 836 0405, 8360143, 836 034. Fax. 8361721.
}

dari yang tidak endemis malaria. Di daerah tersebut, masih sering terjadi letusan wabah yang menimbulkan banyak kematian. ${ }^{1}$

Diagnosis malaria dapat ditegakkan dengan uji mikroskopis dan non mikroskopis. Uji mikroskopis dapat dilihat secara langsung di bawah mikroskop, seperti darah tepi, dan quantitative buffy coat (QBC). Sedangkan pada uji non mikroskopis, identifikasi antigen parasit atau antibodi antiplasmodial atau produksi metabolik parasit, salah satu contoh kitnya adalah rapid manual test. ${ }^{5}$

Tujuan tulisan ini adalah untuk mengetahui berbagai metode rapid manual test untuk diagnosis malaria P.falciparum secara cepat dan mudah.

\section{Rapid Manual Test}

Rapid manual test merupakan uji yang lebih cepat, mudah dilakukan dan tidak memerlukan laboratorium khusus, seperti peralatan centrifuge dan miskroskop. Uji ini lebih praktis digunakan di lapangan. Diagnosis yang cepat dan akurat adalah kunci penanganan yang efektif untuk mengatasi penyakit malaria. Uji ini berdasarkan pada deteksi antigen yang dikeluarkan oleh parasit malaria yang dapat melisiskan darah, menggunakan 
metode immunochromatographic. ${ }^{6}$

Selain histidine rich protein II (HRP-II) sudah dikembangkan pula uji Plasmodium Lactate dehydrogenase $(p L D H)$. Uji ini berdasarkan deteksi soluble glycolyvtic enzym yang dikeluarkan oleh parasit dengan kadar yang tinggi di dalam darah. ${ }^{7}$

Rapid manual test ini dibagi berdasarkan: ${ }^{6}$

\section{A. Histidine Rich Protein II ( HRP-II)}

HRP-II adalah water-soluble protein yang dihasilkan oleh tropozoit dan gametosit muda P.falciparum.

\section{Para-Sight-F}

Uji ini berbentuk stik dengan panjang $7 \mathrm{~cm}$ dan lebarnya $3 / 4 \mathrm{~cm}$; dibuat dari serat nitroselulosa yang mengandung 2 bagian yaitu bagian A mengandung antibodi monoklonal histidine-rich-protein II( HRPII ) dan bagian B mengandung dessicant. ${ }^{3}$

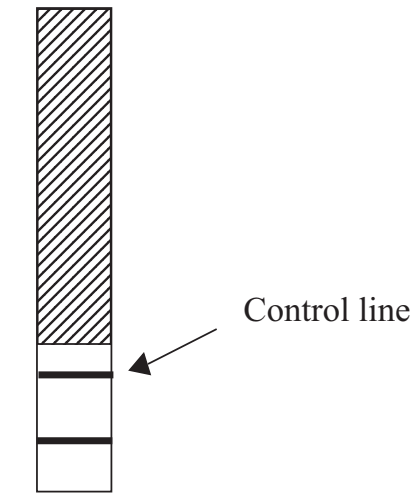

Hasil Positif

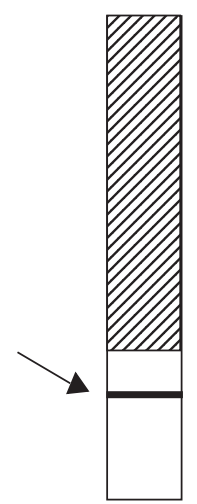

Hasil Negatif
Gambar 1. Gambaran hasil positif dan negatif pada uji ParaSight- $F^{\circledR}$ (Dikutip dari Uguen C.dkk. ${ }^{9}$ )

Cara kerja: Darah diambil dari jari dengan mengunakan mikrohematokrit sebanyak $50 \mu \mathrm{l}$ kemudian dimasukan ke dalam tabung reaksi yang mengandung reagen pelisis sampai bercampur dan menjadi homogen. Selanjutnya satu tetes darah yang telah lisis tadi diteteskan pada stik bagian A kemudian ditunggu sampai darah diserap. Setelah diserap dengan sernpurna ditambahkan satu tetes reagen detektor, kemudian dua tetes reagen pembersih. Dalam waktu sepuluh menit hasilnya dapat dibaca. Bila tidak terdapat antigen dalam darah maka liposom tidak akan terikat, dengan demikian tidak akan terbentuk garis merah pada stik. Garis kontrol tampak di atas garis reaksi baik positif maupun negatif. Intensitas garis reaksi dapat bervariasi tergantung pada jumlah antigen yang terdapat di dalam sampel. ${ }^{3}$

Rumah Sakit International Timber Corporation Indonesia (ITCI), Kenangan Balikpapan, Kalimantan Timur, melaporkan $73,3 \%$ sensitivitas pada rapid manual test dengan spesifisitas $82,5 \%$, nilai prediksi positif $85,2 \%$ dan nilai prediksi negatif $74,6 \%$ dibandingkan cara konvensional. ${ }^{3}$

Beadle di Kenya melaporkan dengan P.falciparum histidine-rich protein II (PfHRP-II) diperoleh 96,5$100 \%$, bila jumlah parasitemia darah $>60 /$ l. Bila jumlah parasitemia darah 11-60 /_l maka nilai sensitivitas $70-81 \%$. Bila jumlah parasitemia darah $<10 \_1$ maka sensitivitas 11-67\%. Uguen dkk, di RS La Croix rousse di Lyon dan RS Alphonse Laveran di Marseilles, Perancis memperoleh hasil spesifisitas dan sensitivitas dari uji ParaSight- $F^{\circledR}$ masing-masing adalah $99 \%$ dan $94 \%$, nilai prediksi positif dan negatif berturut-turut 89\% dan 99\%. ${ }^{9}$ Humar dkk, 1994 melaporkan uji ParaSight- $F^{\circledR}$ dibandingkan dengan PCR dan mikroskopis diperoleh nilai sensitivitas sebesar 88\% dan spesifisitas $97 \% .{ }^{10}$ Omar di Saudi Arabia memperoleh nilai sensitivitas 95-100\% dan spesifisitas $100 \%$, nilai prediksi positif $100 \%$ dan nilai prediksi negatif 91\%. ${ }^{11}$ Genton dkk tahun 1995 meneliti diagnosis pada infeksi P.falciparum dengan memakai uji ParaSight ${ }^{\circledR}$ dalam darah dan dalam urin pada anak-anak Papua New Guinea didapatkan hasil sensitivitas dalam darah $84 \%$ dari spesifisitas $77 \%$ dibandingkan dalam urin nilai sensitivitas sebesar $81 \%$ dan spesifisitas hanya 26\%. Oleh karena spesifisitas dalam urin rendah sehingga tidak direkomendasikan uji ParaSight $^{\circledR}$ dalam urin. ${ }^{12}$

\section{Paracheck}

Berbentuk stik, strips ini dibuat dari flatted fibre wick panjangnya $3 \mathrm{~cm}$ dan lebarnya $0,5 \mathrm{~cm}$. Bagian A mengandung antibodi monoklonal yang bereaksi terhadap histidine rich protein II. ${ }^{13}$

Cara kerja: Strips Paracheck dapat disimpan pada suhu kamar. Darah diambil sebanyak $5 \mu$ l dengan pipet aplikator atau mikropipet. Teteskan darah di bawah tanda panah yang ada pada dipstik. Celupkan dipstik ke dalam tabung yang mengandung larutan bufer 4 tetes $(200 \mu \mathrm{l})$, setelah 15 menit dapat dibaca hasilnya. Interprestasi hasil, bila negatif hanya 1 garis berwarna 


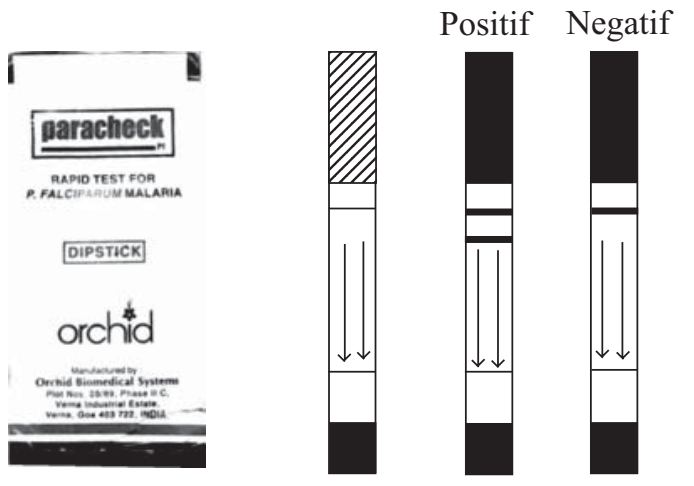

Gambar 2. Gambaran hasil positif dan negatif pada Paracheck $^{\circledR}$ (Dikutip dari Orchid)

merah jambu yang terlihat pada dipstik, bila hasil positip terlihat 2 garis berwarna merah jambu yang jelas. ${ }^{13}$

Penelitian kit ini telah dilakukan pada Department of Pediatrics, M.L.Medical College, Jhansi(UP) pada 192 anak. Hasil penelitian ini didapatkan nilai sensitivitas $81,25 \%$ dan spesifisitas $90 \% .^{13}$

\section{ICT =Immunochromatographic test.}

Berbentuk kartu segi empat, uji ini menggunakan 2 antibodi yang spesifik terhadap antigen P.f HRP- II. Pertama spesifik terhadap PS HRP-II (protein P.falciparum) antigen, yang kedua antibodi analog spesifik terhadap P.falciparum dan antigen P.vivax. ${ }^{14}$

Cara Kerja: Kurang lebih $10 \mathrm{mI}$ darah diteteskan pada bantalan sampel, kemudian proses lisis terjadi dan antigen PfHRP II (bila ada) akan mengikat antibodi yang berlabel koloidal emas. Ketika reagen A ditambahkan pada bantalan sampel, darah dan antibodi berlabel bergerak ke atas pada membran tes melewati garis antibodi kedua. Apabila sampel positif kompleks Pf HRP II dengan antibodi berlabel koloidal emas ditangkap oleh antibodi pada membran dan berbentuk garis warna merah muda. Untuk sampel negatif tidak terjadi pembentukan garis berwarna merah muda pada garis tes. ${ }^{14}$

Thepsamaran dkk. memakai uji ICT $^{\circledR}$ untuk mendeteksi P. falciparum di R.S. Somdej Prachao Taksin, Thailand. Diperoleh sensitivitas 92,7\%, spesifisitas $95,1 \%$, nilai prediksi positif $74,5 \%$ nilai prediksi negatif $98,8 \%$ dan akurasi $94,7 \%$. Lima belas penelitian di Sumba, Indonesia pada tahun 1998 dengan menggunakan kit ICT ${ }^{\circledR}$ malaria P-f/P-v didapat nilai sensitivitas $95,5 \%$ dan spesifisitas $89,8 \%$, nilai prediksi positif $88,1 \%$ dan nilai prediksi negatif 96,2 \% untuk Plasmadium falciparum. Sedangkan untuk Plasmodium vivax sensitivitas $75 \%$ dan spesifisitas $96 \%$, nilai prediksi positif 50\% dan nilai prediksi negatif 98,2\%. Plasmodium vivax dapat meningkat sensitivitasnya bila parasetemia meningkat $>500 / \mu 1$ maka nilai sensitivitas 96\%, tetapi bila parasetemia $<500 \mu \mathrm{l}$ maka sensitivitasnya $29 \% .{ }^{16} \mathrm{Di}$ Penyabungan, Mandailing Natal, Sumatra Utara pada tahun 2001 dilakukan penelitian perbandingan pewarnaan Giemsa dengan ICT ${ }^{\circledR}$. Diperoleh hasil nilai sensitivitas $76 \%$, spesifisitas $68 \%$, nilai prediksi positif $73 \%$, nilai prediksi negatif $72 \%$ dan akurasi $72 \% .{ }^{17}$
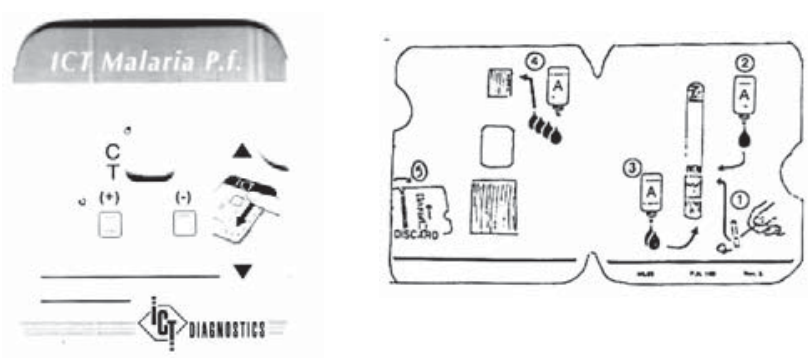

Gambar 3. Gambaran hasil positif dan negatif pada ICTO ( Dikutip dari AMRAD ICT. ${ }^{14}$ )

\section{B. Parasite Lactate Dehydrogenese (pLDH)}

Parasite lactale dehydrogenese dihasilkan oleh stadium aseksual dan seksual (gametosit) oleh parasit malaria. Kit ini (Gambar 4) untuk mendeteksi pLDH dari sernua 4 spesies Plasmodium. Kit ini dapat membedakan $P$. falciparum dan non falciparum tetapi tidak dapat dibedakan antara P. vivax, P. ovale dan P. malariae. Antigen $\mathrm{pLDH}$ dijumpai dan disekresi oleh eritrosit
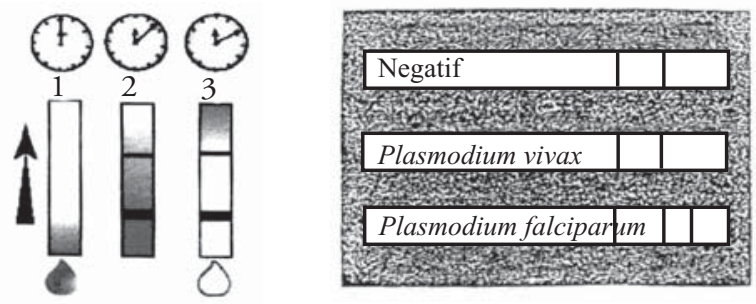

Gambar 4. Gambaran hasil positif P.vivax,P.Falciparum dan hasil negatif pada optiMAL ${ }^{\circledR}$ (Sumber Palmer) 
yang telah terinfeksi oleh parasit. Perbedaan parasit malaria berdasarkan perbedaan antigen pLDH isoform. ${ }^{6,7}$

Contoh kit adalah $O p t i M A L^{\circledR}$, uji ini berbentuk dipstik dilapisi antibodi monoklonal terhadap enzim metabolik intraselular pLDH, dan dapat dilakukan di lapangan. ${ }^{18}$

Cara kerja

1. Darah diambil dari jari pasien dengan menggunakan finger stick sebanyak $10 \mu$ l kemudian ditambahkan $30 \mu \mathrm{l}$ larutan bufer ke dalam tabung sampai bercampur selama 60 detik.

2. Celupkan uji strip optiMAL ${ }^{\circledR}$ (bagian yang tipis di bawah) kemudian diangkat dan biarkan darah naik ke bagian atas uji strip dalam waktu 10 menit. Untuk sampel yang tidak naik dengan sempurna, pindahkan tes strip sesudah 15 menit ke langkah ke 3.

3. Celupkan uji strip pada tabung ke 2 yang berisi larutan buffer $100 \mu \mathrm{l}$ (4-5 tetes). Dalam 10 menit hasilnya dapat dibaca. Bila positif P.vivax tampak satu garis melintang pada uji strip selain garis kontrol. Apabila tes positif P.falciparum tampak garis dua melintang pada tes strip selain garis kontrol, bila negatif hanya tampak garis kontrol saja. ${ }^{18,19}$

Penelitian yang dilakukan Trujillo di Honduras Utara pada tahun 1997 didapatkan hasil nilai sensitivitas untuk P.falciparum dan P. vivax adalah 94\% dan $88 \%$, nilai spesifisitas $100 \%$ dan $99 \%$, nilai prediksi positif $88 \%$ dan $100 \%$, nilai prediksi negatif 99\% dan 96\%. ${ }^{18}$ Di Berlin Rumah Sakit Virchow Campus melakukan perbandingan optiMAL ${ }^{\circledR}$ dengan ICT $^{\circledR}$, dengan hasil nilai sensitivitas ICT $^{\circledR} 92,5 \%$ dan nilai spesifisitas $98,3 \%$, nilai prediksi positif $94,2 \%$ dan nilai prediksi negatif $97,8 \%$. Dibandingkan dengan optiMAL ${ }^{\circledR}$ nilai sensitivitas adalah $88,7 \%$, nilai spesifisitas $99,4 \%$, nilai prediksi positif $97,9 \%$ dan nilai prediksi negatif 96,7\%. ${ }^{20}$ Medical Research Council Gambia mendapat nilai sensitivitas $91,3 \%$, spesifisitas $92 \%$, nilai prediksi positif $87,2 \%$ dan nilai prediksi negatif $94,7 \% .^{21}$

\section{Kesimpulan}

Di Indonesia sampai saat ini penyakit malaria masih merupakan masalah kesehatan masyarakat. Hal ini terbukti dari angka kesakitan penyakit malaria masih tinggi. Diagnosis malaria harus ditegakkan secepat dan seakurat mungkin untuk segera diberikan penanganan yang tepat. Metode diagnosis yang baru adalah rapid manual test yang telah diuji di beberapa negara menghasilkan tes yang mudah, cepat dan tidak memerlukan laboratorium khusus, mempunyai nilai sensitivitas dan spesifisitas rata-rata di atas $90 \%$.

\section{Daftar Pustaka}

1. Rampengan TH. Malaria. Dalam: Rampengan TH, Laurantz IR, Penyunting. Penyakit infeksi tropik pada anak. Jakarta: EGC, 1990. h. 185-204.

2. Poolsuwan S. Malaria in prehistoric Southeastern Asia. Southeast J Trop Med Publ Health 1995; 26:3-22.

3. Susanto L, Pribadi W, Astuty H. Diagnosis of malaria by the rapid manual test. Med J Indones 1995; 4:24-9.

4. Diallo AB, Serres GD, Beavogui AB, Lapointe C, Viens P. Home care of malaria-infected children of less than 5 years of age in a rural area of the Republic of Guinea.WHO 2001; 79:28-31.

5. Kakkilaya BS. Diagnosis of malaria.B. S. Kakkilaya's Malaria Web Site. Didapat dari URL:http://www.geocities.com/ HotSprings/Resort/5403/.me://A:/Diagnosis of malaria.htm

6. WHO New perspctives malaria diagnosis. Report of ajoint WHO/ Usaid informal consultation. WHO 1999:11-30.

7. Piper R, Lebras J, Wentworth L, Hunt-cooke A, dkk. Immunocapture diagnostic assays for malaria using Plasmodium lactate dehydrogenese (pLDH). Am J Trop Med Hyg 1999; 60:109-118.

8. Beadle C, Long WG, Weiss RW, dkk. Diagnosis of malaria by detection of Plasmodium falciparum HRP-2 antigen with a rapid dipstick anti gen-capturte assay. Lancet 1994; 343:564-8.

9. Uguen C, Rabodonirina M, De pina JJ, dkk. ParaSightF rapid manual diagnostic test of Plasmodium falciparum infection. WHO Bulletin OMS 1995; 73:644-9.

10. Humar A, Ohrt C, Harrington MA, Pillai D, Kam KC. ParaSight $\mathrm{F}$ test compared with the polymerase chain reaction and microscopy for the diagnosis of Plasmodium falciparum malaria in travelers. Am.J.Trop.Med.Hyg 1997; 56:44-8.

11. Omar MS, Malik GM,Al-Amari OM, dkk. The rapid manual ParaSight $\mathrm{f}$ test for diagnosing Plasmodium falciparum malaria in Saudi Arabia. Didapat dari URL:http://www.kfshrc.edu.sa/annals/192/98-163.html.

12. Genton B, Beck HP, Gibson N. Diagnosis of Plasmodium falciparum infection using ParaSight test in blood and urine of papua New Guinean children. South east Asia J Trop Med Publ Health 1998; 29:35-40.

13. Kaushik A, Gahlot S, Kaushik S, Verma.131 Rapid manual test for falciparum malaria. Indian Pediatr 2001; 38:650-4.

14. Informasi produk.AMRAD ICT malaria P.f/P.v 
15. Thepsmarn P, Prayoollawongsu N, Puksupa P, dkk. The ICT malaria PF: a sample rapid dipstick test for diagnosis of Plasmodium falciparum malaria at the ThaiMyanmar boerder. Southeast Asian J Trop Med Pubi Hlth 1997; 28:723-6.

16. Tjitra E, Suprianto S, Dyer M, dkk. Flied evaluation of the ICT malaria P.f/P. immunochromatographic test for detection of Plasmodium falciparum and Plasmodium vivax in patients with a presumptive clinical diagnosis of malaria in eastern Indonesia. J Clin Microbiol 1999; 37:2412-7.

17. Desrinawati, Pasaribu S, Lubis M, dkk. Perbandingan hasil pemeriksaan metode ICT (Immunochromatographic test) dengan pewarnaan Giemsa pada malaria falciparum. Di sampaikan pada Pertemuan Ilmiah Tahunan Ikatan Dokter Anak Indonesia 1, Palembang, 25-27 Juni, 2001.

18. Palmer CJ, Lindo JF, Klaskala WI, dkk. Evaluation of the optiMAL test for rapid diagnosis of Plasmodium vivax and Plasmudium falciparum malaria. J Clin Microbiol 1998; 26:203-6.

19. OptiMAL_ rapid manual test. The OptiMAL_Assay-A specie specific, Malaria test and diagnostic utility for your trevels. Available from URL:http://www.malariatest.com/ test Principle.

20. Jelinek T, Grobbusch MY, Schwenke S, dkk. Sensitivity and specificity of dipstick test for rapid diagnosis of malaria in nonimmune travelers. J Clin Microbiol 1999; 37:721-3.

21. Cooke ah, Chiodini PL, Doherty T, dkk. Comparison of a parasite lactate dehydrogenase- based immunochromatographic antigen dectetion assay (optimal) with microscopy for the dectetion of malaria parasites in human blood samples. Am J Trop Med Hyg 1999; 60:173-6. 